\title{
Dynamic Changes of Excitatory Amino Acid Receptors in the Rat Hippocampus Following Transient Cerebral Ischemia
}

\author{
Eva Westerberg, ${ }^{1}$ Daniel T. Monaghan, ${ }^{2}$ Hannu Kalimo, ${ }^{3}$ Carl W. Cotman, ${ }^{2}$ and Tadeusz W. Wieloch ${ }^{1}$ \\ 'Laboratory for Experimental Brain Research, University of Lund, Lund Hospital, S-221 85 Lund, Sweden, 'Department of \\ Psychobiology, University of California Irvine, Irvine, California 92717, and ${ }^{3}$ Department of Pathology, Turku University \\ Hospital, SF-20520 Turku, Finland
}

The changes in excitatory amino acid receptor ligand binding induced by transient cerebral ischemia were studied in the rat hippocampal subfields. Ten minutes of ischemia was induced by common carotid artery occlusion combined with hypotension, and the animals were allowed variable periods of recovery ranging from 1 day to 4 weeks. The binding of ${ }^{3} \mathrm{H}$-AMPA ( $\alpha$-amino-3-hydroxy-5-methyl-4-isoxazolepropionic acid) to quisqualate receptors, ${ }^{3} \mathrm{H}-k$ ainic acid (KA) to kainate receptors, and ${ }^{3} \mathrm{H}$-glutamate to $\mathrm{N}$-methyl-D-aspartate (NMDA) receptors as determined by quantitative autoradiography.

One week following ischemia the CA1 region of the hippocampus displayed a severe $(90 \%)$ dendrosomatic lesion with preservation of presynaptic terminals. This was associated with a $60 \%$ decrease in AMPA binding and a $25 \%$ decrease in glutamate binding to NMDA receptors. At 4 weeks postischemia, both AMPA and NMDA sites were greatly reduced. Although the dentate gyrus granule cells are resistant to an ischemic insult of this magnitude, this region showed marked changes in receptor binding. One weok following ischemia, the AMPA and NMDA binding decreased by approximately $\mathbf{4 0}$ and $20 \%$, respectively. Following 2 weeks of recovery, the NMDA binding was not significantly different from control level, while the AMPA binding remained depressed up to 4 weeks postischemia. The high density of $\mathrm{KA}$ binding sites in the inner molecular layer of the dentate gyrus was unaffected by the ischemic insult, despite an extensive degeneration of cells in the hilus of dentate gyrus which projects glutamatergic afferents to this area.

The results demonstrate a progressive loss of AMPA and glutamate (NMDA) binding in the CA1 region of the hippocampus over 4 weeks, presumably related to cell loss. The loss of AMPA binding occurred faster than the loss of glutamate binding to NMDA-sensitive sites. A sustained loss (2-4 weeks) of AMPA binding occurred in regions without cell loss and may have functional implications.

\footnotetext{
Received Mar. 28, 1988; revised July 13, 1988; accepted July 28, 1988.

This work was supported by grants from the Swedish Medical Research Council (No 14X-263 and 4X-08644), the USPHS (2ROI NS-07838 and IROI NS-25302), Grant DAAL 03-86-K-0067, and the Finnish Medical Research Council. We thank Anne-Marie Rohrstock and Lena Sjöberg for technical assistance and Stefan Seth for IBAS computer programming and photography.

Correspondence should be addressed to Eva Westerberg at the above address. Copyright (C) 1989 Society for Neuroscience $0270-6474 / 89 / 030798-08 \$ 02.00 / 0$
}

Transient cerebral ischemia leads to neuronal damage in hippocampal CAl and in the hilus of the dentate gyrus (Ito et al., 1975; Pulsinelli et al., 1982a; Smith et al., 1984a). In the CA1 region of dorsal hippocampus, the morphology of pyramidal neurons appears normal for the first day or two following ischemia, but with longer recovery periods the cells succumb. The adjacent CA3 region is relatively more resistant to ischemia, as are the dentate gyrus granule cells.

During the past few years, the involvement of excitatory amino acid (EAA) transmission in the development of ischemic brain damage has been largely recognized (Jørgensen and Diemer, 1982; Rothman, 1983; Wieloch, 1985). Transection of the excitatory afferents, to the hippocampus from the entorhinal cortex (perforant path), a glutamatergic pathway, is protective against ischemia-induced damage in the CA1 region (Wieloch et al., 1985; Jørgensen et al., 1987). Neurons in this region are also protected against ischemia, by destruction of the dentate gyrus granule cells by i.c.v. injection of colchicine, breaking the trisynaptic excitatory input from the entorhinal cortex to the CAl region (Johansen et al., 1987). Furthermore, intrahippocampal injection of a competitive $N$-methyl-D-aspartate (NMDA) antagonist, 2-amino-7-phosphono-heptanoic acid (AP7), prevents acute ischemic cell changes in the rat (Simon et al., 1984), and systemic administration of a noncompetitive NMDAreceptor antagonist (MK-801) reduces, ischemia-induced neuronal damage in the CAl of the gerbil (Gill et al., 1987). Thus, EAAs appear to participate in ischemia-induced damage. It is not known what the effects of ischemia on the EAA receptors are, however.

Receptors for EAA transmitters have been divided into 3 subclasses according to their selective agonists, NMDA, quisqualic acid (QUIS) and kainic acid (KA) (Watkins and Evans, 1981). The hippocampus is rich in EAA receptors of all 3 subclasses (Monaghan et al., 1983), but they are unevenly distributed within the structure. The CAl region is rich in NMDA and QUIS receptors, while KA receptors are concentrated to the stratum lucidum of the CA3 region and the inner third of the molecular layer of the dentate gyrus.

We have previously demonstrated that ${ }^{3} \mathrm{H}-\alpha$-amino-3-hydroxy-5-methyl-4-isoxazolepropionic acid ( ${ }^{3} \mathrm{H}$-AMPA) binding to QUIS receptors is selectively decreased during ischemia and in the immediate recirculation period, and that a second loss of AMPA binding precedes the cell death in vulnerable regions (Westerberg et al., 1987). In contrast, binding to NMDA and KA receptors was unchanged until the fourth day of recovery. At this time point, neuronal necrosis is evident, but the binding 
to NMDA receptors is decreased only by $20 \%$. In the present study, we have extended the recovery period up to 4 weeks to further characterize the long-term changes in the binding to different excitatory amino acid receptor subtypes.

\section{Materials and Methods}

Animals. Male Wistar rats (Møllegard Avlslaboratorium, Copenhagen) weighing $250-420 \mathrm{gm}$ were used in this study. The animals were starved during the night preceding the operation but had free access to tap water. Anesthesia was induced with $3.5 \%$ halothane, and the rats were intubated and connected to a Starling-type respirator delivering $0.7 \%$ halothane and $30 \% \mathrm{O}_{2}$ in $\mathrm{N}_{2} \mathrm{O}$. Muscle paralysis was achieved with suxamethoniumchloride ( $1 \mathrm{mg} / \mathrm{kg}$ i.v. boluses every $15-20 \mathrm{~min})$. Tail artery and venous catheters were inserted and common carotid arteries were isolated via a neck incision. A silicon catheter was advanced into the inferior caval vein via the right jugular vein to minimize exsanguination time at the onset of ischemia. EEG was registered by bipolar interhemispheric recording. The halothane was then discontinued, and the rat was allowed a steady-state period of $30 \mathrm{~min}$. Incomplete cerebral ischemia was induced by bilateral common carotid artery occlusion combined with hypotension (Smith et al., 1984b). Briefly, when the blood pressure fell to $80 \mathrm{~mm} \mathrm{Hg}$ following trimethaphan administration (3 $\mathrm{mg} / \mathrm{kg}$, i.v.), the common carotid arteries were clamped and blood was withdrawn from the jugular vein to a blood pressure of $40-50 \mathrm{~mm} \mathrm{Hg}$. The EEG activity was recorded, and cessation of EEG activity was used as an indicator of the onset of ischemia. Following $10 \mathrm{~min}$ of ischemia, blood pressure was restored, and the carotid clamps were removed. A volume of $0.7 \mathrm{ml}$ of $0.6 \mathrm{M}$ sodium bicarbonate was administered i.v. Arterial $\mathrm{PO}_{2}, \mathrm{PCO}_{2}$, and $\mathrm{pH}$ were maintained at $90-110 \mathrm{~mm} \mathrm{Hg}, 35$ $40 \mathrm{~mm} \mathrm{Hg}$, and $7.35-7.40$, respectively. The body temperature was kept at $37^{\circ} \mathrm{C}$.

Tissue preparation. At the end of the ischemic period or after the desired period of recovery, the rat was decapitated and the brain was quickly removed from the skull and frozen in isopentane chilled to

$-50^{\circ} \mathrm{C}$. The rat brains were stored at $-80^{\circ} \mathrm{C}$ until used. Brain sections $(6 \mu \mathrm{III})$ were cul in a cryostat (Bright) at $-20^{\circ} \mathrm{C}$ and thaw-mounted onto subbed microscope slides. The tissue sections were stored at $-20^{\circ} \mathrm{C}$ overnight. Parallel sections were taken for histological evaluation of neuronal damage.

Histopathological techniques. The tissue sections were fixed for at least $1 \mathrm{~min}$ in formalin-ethanol (conc. formaldehyde, 96\%/ethanol, 1:3, vol/ vol) prior to staining with celestine blue and acid fuchsin. The sections were immersed in celestine blue solution (ammonium iron sulfate 5.0 $\mathrm{gm}$, distilled water $100 \mathrm{ml}$, conc. hydrochloric acid $0.5 \mathrm{ml}$, celestine blue $5.0 \mathrm{gm}$ ) for $20 \mathrm{sec}$ to $10 \mathrm{~min}$, then washed in tap water for $5 \mathrm{~min}$, distilled water for $1 \mathrm{~min}$, and immersed in acid fuchsin solution (1\%) for 1 min. Following immersion in glacial acetic acid solution for 2-3 $\mathrm{min}$, the slides were washed again in tap water and distilled water for 1-2 sec; dehydrated rapidly twice in each $95 \%$ alcohol, absolute alcohol, and finally in xylene; and mounted with Pertex.

For electron microscopy (EM) the brains of 2 rats exposed to 10 min ischemia followed by $7 \mathrm{~d}$ recovery were fixed by intravascular perfusion with $3 \%$ glutaraldehyde in $0.1 \mathrm{M}$ phosphate buffer $\left(\mathrm{pH} 7.4,37^{\circ} \mathrm{C}\right.$ and at a pressure of $180 \mathrm{~cm} \mathrm{H}_{2} \mathrm{O}$ ) preceded by a short rinse with physiological saline. After removal from the skull, the brains were stored in the same fixative until processed further. Thin coronal slices $(500 \mu \mathrm{m})$ were cut with a manual tissue sectioner from the hippocampus of both sides, postosmicated, stained en bloc with uranyl acetate, dehydrated in graded ethanol, and embedded flat in Epon. Semithin sections stained with toluidine blue were used for high-resolution light microscopy and selection of areas for taking thin sections, which were then stained in an LKB Ultrostainer and examined with a JEM $100 \mathrm{C}$ electron microscope.

Binding to EAA-receptors. The NMDA-displaceable binding of 100 nM ${ }^{3} \mathrm{H}$-glutamate $(41.5 \mathrm{Ci} / \mathrm{mmol}$, New England Nuclear, FRG) was quantified in $50 \mathrm{~mm}$ Tris-acetate, $\mathrm{pH} 7.2$, containing $5 \mu \mathrm{M}$ quisqualic acid and $100 \mu \mathrm{M}$ SITS (4-acetamido-4'-isothiocyano-stilbene-2,2'-disulfonic acid). Following $1 \mathrm{hr}$ at $0^{\circ} \mathrm{C}$, the sections were preincubated for $2 \times 10 \mathrm{~min}$ in $50 \mathrm{~mm}$ Tris-acetate at $30^{\circ} \mathrm{C}$ and incubated at $0^{\circ} \mathrm{C}$ with tritiated glutamate for $10 \mathrm{~min}$. The sections were rinsed in 4 baths of Tris buffer at $0^{\circ} \mathrm{C}$ over $30 \mathrm{sec}$ total and dried in an air stream.

Binding of $100 \mathrm{nM}{ }^{3} \mathrm{H}$-AMPA $(26.6 \mathrm{Ci} / \mathrm{mmol}$, NEN) to quisqualate

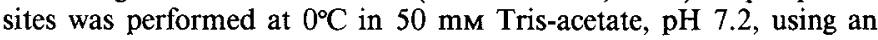

incubation time of $30 \mathrm{~min}$. In order to obtain the AMPA-binding constants, consecutive sections from dorsal hippocampus from animals in control, ischemia, and 1 and $2 \mathrm{~d}$ recirculation groups were incubated with 9 different concentrations of ${ }^{3} \mathrm{H}$-AMPA between 5 and $500 \mathrm{nM}$ The sections were preincubated, rinsed, and dried as described above.

Binding to KA sites was performed in $50 \mathrm{~mm}$ Tris-citrate, $\mathrm{pH} 7.0$. The sections were exposed to $50 \mathrm{~nm}{ }^{3} \mathrm{H}$-kainic acid for $30 \mathrm{~min}$ at $0^{\circ} \mathrm{C}$ in this buffer and preincubated, rinsed, and dried as described for the NMDA-sensitive sites.

Nonspecific binding of the 3 agonists was determined with $100 \mu \mathrm{M}$ NMDA, $100 \mu \mathrm{M}$ QUIS, or $100 \mu \mathrm{M}$ KA present in the incubation mixture, respectively. Nonspecific binding to NMDA sites amounted to less than $15 \%$ of total binding, while nonspecific binding to AMPA and KA sites was less than $5 \%$ of the total binding. Specific binding was calculated as the difference between total and nonspecific binding.

Autoradiography. The radiolabeled tissue sections were placed in $\mathrm{X}$-ray cassettes against tritium-sensitive film ( ${ }^{3} \mathrm{H}$-Ultrofilm, LKB, Bromma, Sweden) with one set of tritium standards (American Radiolabeled Chemicals Inc., St. Louis), calibrated against brain paste standards (Unnerstall et al., 1982), per sheet of film. Following an exposure time of $20-30 \mathrm{~d}$ at $4^{\circ} \mathrm{C}$, the films were devcloped according to the manufacturer's instructions. Gray values were obtained using an IBAS image processing system (Kontron, Munich, FRG) with video camera. From a $512 \times 512$ pixel image of one hippocampus, the areas of interest were selected and the gray values within these areas averaged. The average of 4 different brain sections, i.e., 8 hemispheres from each rat represents one data point.

Measurement of tissue quenching. In order to study white and gray matter differences in tritium quenching, ${ }^{3} \mathrm{H}$-2-deoxy-D-glucose $\left({ }^{3} \mathrm{H}-2-\right.$ DG) was used as tracer (Geary et al., 1985). Two sham-operated control rats and 2 rats subjected to $10 \mathrm{~min}$ of ischemia, followed by 2 weeks of recovery, were used in these experiments. Essentially the same procedure as described by Sokoloff et al. (1977) for ${ }^{14} \mathrm{C}-2$-deoxy-D-glucose was applied. Forty-five minutes following intravenous injection of 250 $\mu \mathrm{Ci}{ }^{3} \mathrm{H}-2-\mathrm{DG}$, the rats were killed by decapitation, and the brains were quickly removed from the skull and frozen in isopentane chilled to $-50^{\circ} \mathrm{C}$ in liquid nitrogen. The frozen brains were sectioned $(20 \mu \mathrm{m})$ at $-20^{\circ} \mathrm{C}$ and thaw-mounted onto microscope slides. One set of slides was treated for $5 \mathrm{~min}$ with chloroform at room temperature. The chloroform-treated and nontreated sections were placed together in an X-ray cassette with one set of precalibrated plastic tritium standards (American Radiolabeled Chemicals Inc.) against tritium-sensitive film ( ${ }^{3} \mathrm{H}-\mathrm{U}$ trofilm, LKB). The film was exposed for 4 weeks at $+4^{\circ} \mathrm{C}$ and developed, and the optical densities were analyzed using an IBAS image processing system.

\section{Results}

\section{Pathology}

The pathological changes observed in consecutively cut sections from the same brains where EAA receptor binding was determined were similar to those reported earlier (Pulsinelli et al., 1982a, Smith et al., 1988). One day following ischemia, cell necrosis was evident in the hilar region of dentate gyrus (CA4). A few scattered pyramidal neurons in the medial CAl region also appeared darker than normal cells in 2 of the animals, while the lateral portion was normal. Following $2 \mathrm{~d}$ of recirculation, dense neuronal damage was found in the entire CA1 region in 4 out of 6 animals, amounting to 90 and $75 \%$ in the medial and lateral CA1 regions, respectively. In the remaining 2 rats, approximately $50 \%$ of the pyramidal neurons in medial CAl region were acidophilic, while only scattered neurons in the lateral CA1 were affected. All 6 animals had damaged neurons in cortical layers 3 and 4 . After 1 week of recovery, dense neuronal necrosis was found in the entire CAl region in all animals. As the recovery time was prolonged to 2 or 4 weeks, the dark pyramidal neurons had disappeared from the tissue, indicating that the darkly stained neurons found earlier in the recirculation period in fact had suffered irreversible cell damage. Severe tissue shrinkage in the CAl region was also observed 4 weeks postisch- 


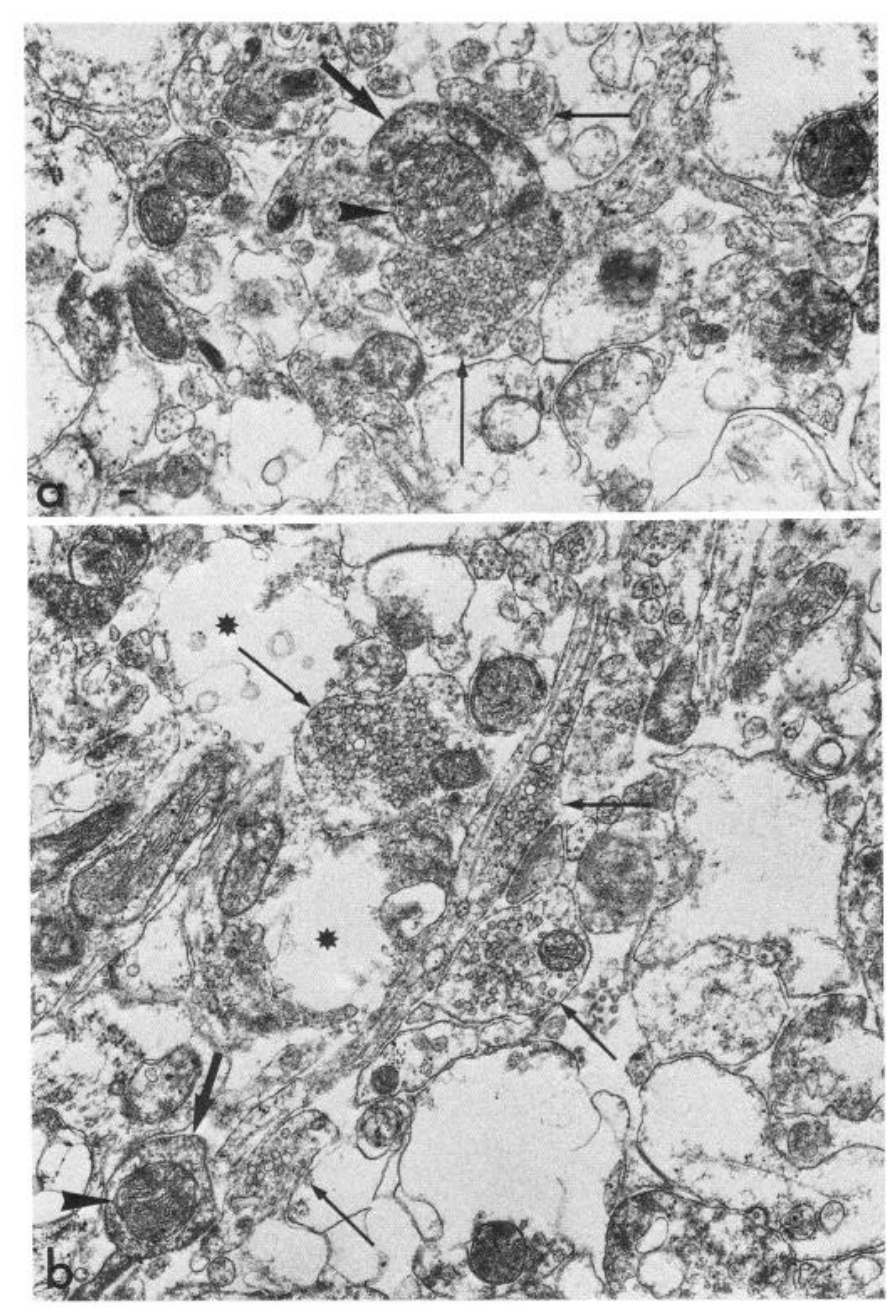

Figure 1. Electron micrographs from stratum radiatum of CAl in a rat exposed to $10 \mathrm{~min}$ ischemia followed by 1 week of recovery. Dendritic processes are extensively degenerated with condensation (thicker arrows) or swelling (asterisk) of their cytoplasm. Dendritic mitochondria with intramatrical densities (arrowheads), breakdown of microtubuli, and breaks of plasma membrane. Presynaptic elements are relatively preserved with normal mitochondria and numerous synaptic vesicles (thin arrows). $\times 20,000$.

emia. The granule cells of the dentate gyrus and CA3 pyramidal neurons were resistant to the ischemic insult, and no necrotic neurons could be observed at any of the time points studied.

The 2-vessel occlusion model of ischemia in the rat generally gives reproducible neuronal damage in well-defined areas of the brain (Smith et al., 1984a). However, the regional and temporal development of the damage is dependent both on the length of the ischemic insult and the density of ischemia. In our previous study (Westerberg et al., 1987), no neuronal necrosis was found in the lateral CA1 subfield $2 \mathrm{~d}$ following $10 \mathrm{~min}$ of ischemia, and only scattered damaged neurons in the medial CA1. In contrast, the present experiments show severe pyramidal cell loss in the entire CA1 in 4 of 6 animals, and in the medial CA1 in all 6 animals, following $10 \mathrm{~min}$ of ischemia with $2 \mathrm{~d}$ of recirculation. Thus, the density of the ischemic insult was higher in the present study than in the previous one.

The ultrastructural changes in the stratum radiatum of CA1 at 1 week after 10 min of ischemia is shown in Figure $1, a, b$. The tissue was markedly spongy with extensive disintegration of dendrites, which appeared either as condensed (Fig. 1a) or secondarily swollen structures with numerous breaks in their plasma membrane (Fig. $1 b$ ). Their mitochondria commonly had intramatrical densities (Fig. 1a), and destruction of microtubuli and neurofilaments was noted. The presynaptic elements were preserved with an intact plasma membrane and an abundance of synaptic vesicles.

\section{Binding to NMDA receptors}

The stratum radiatum and stratum oriens of $\mathrm{CA} 1$ and the outer two-thirds of the molecular layer of the ventral blade of dentate gyrus were the hippocampal regions with the highest NMDA receptor densities (Table 1, Fig. 2). All these regions had a NMDA-displaceable ${ }^{3} \mathrm{H}$-glutamate binding in control animals of approximately $1800 \mathrm{fmol} / \mathrm{mg}$ protein, when a ligand concentration of $100 \mathrm{~nm}$ was used. No significant changes in the NMDAsensitive glutamate binding were noted during ischemia or reperfusion up to $24 \mathrm{hr}$ following the ischemic insult. At this time glutamate binding was reduced by $20-25 \%$ in all structures studied except the ventral blade of dentate gyrus. When analyzing individual animals, the 2 brains showing no neuronal necrosis in the CA1 region at $48 \mathrm{hr}$ recovery also displayed a $20-25 \%$ decrease in NMDA-displaceable glutamate binding. Thus, there was no clear correlation between neuronal necrosis and this decrease in binding to NMDA receptors.

Prolongation of recovery resulted in further loss of NMDA binding sites. NMDA-sensitive ${ }^{3} \mathrm{H}$-glutamate binding in stratum radiatum of CA1 was reduced to approximately 75,40 , and $20 \%$ of control binding at 1 week, 2 weeks, and 4 weeks following the ischemic insult, respectively (Fig. 3). An interesting difference was noted in the dentate gyrus. While the binding to the ventral blade remained at control level, a significant reduction in binding in the dorsal blade of dentate gyrus was observed after $2 \mathrm{~d}$ and 1 week of recovery. This reduction was no longer present 2 weeks postischemia.

\section{Binding to QUIS receptors}

The highest density of QUIS receptors, as reflected by the binding of ${ }^{3} \mathrm{H}$-AMPA (1797 $\pm 131 \mathrm{fmol} / \mathrm{mg}$ protein), was found in the pyramidal cell layer of CA1 (Table 1, Fig. 2). High binding was also found in the dendritic layers of the same regions and in the molecular layer of the dentate gyrus. As previously shown (Westerberg et al., 1987), ischemia induces a transient decrease in binding that is reversed $1 \mathrm{hr}$ following ischemia. This reduction in binding was found also in this study. Two days following the ischemic insult, ${ }^{3} \mathrm{H}$-AMPA binding was significantly reduced to approximately $60 \%$ of control value in all regions measured, except the ventral blade of dentate gyrus. As the recovery was prolonged, binding was further reduced in stratum radiatum of the CA1, by 55,65 , and $85 \%$ of control value at 1,2 , and 4 weeks following ischemia, respectively (Fig. 3). ${ }^{3} \mathrm{H}$-AMPA bind-

Figure 2. Color-coded images of NMDA displaceable ${ }^{3} \mathrm{H}$-glutamate (100 nM) binding and ${ }^{3} \mathrm{H}-\mathrm{AMPA}(100 \mathrm{nM})$ binding in fmol (mg protein) ${ }^{-1}$, to rat hippocampal sections from a control animal and 1, 2, and 4 weeks following 10 min of ischemia. Lower panel shows binding of 50 nM ${ }^{3} \mathrm{H}-\mathrm{KA}$ to the dentate gyrus of a control animal and an animal subjected to $10 \mathrm{~min}$ of ischemia followed by 4 weeks of recovery. 
AMPA

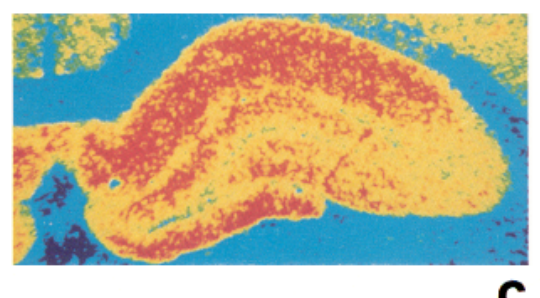

C
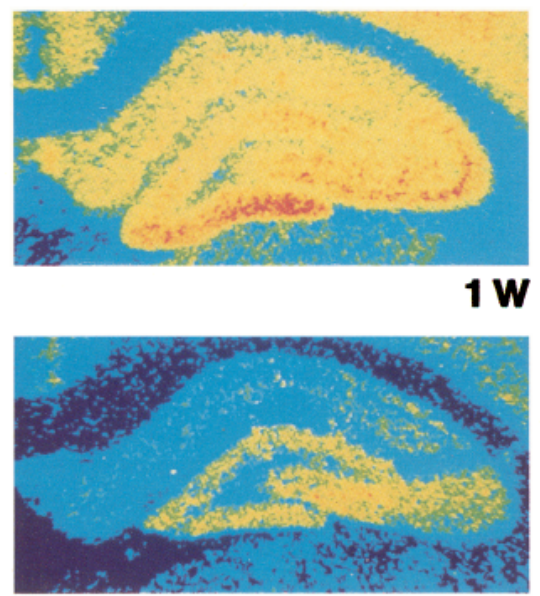

$2 \mathrm{~W}$

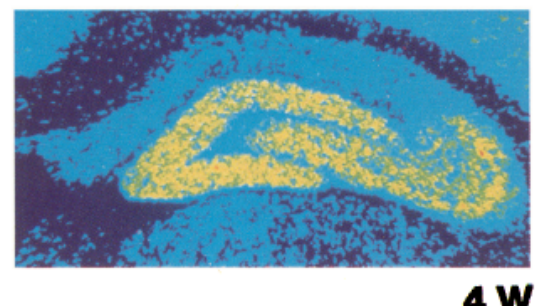

NMDA
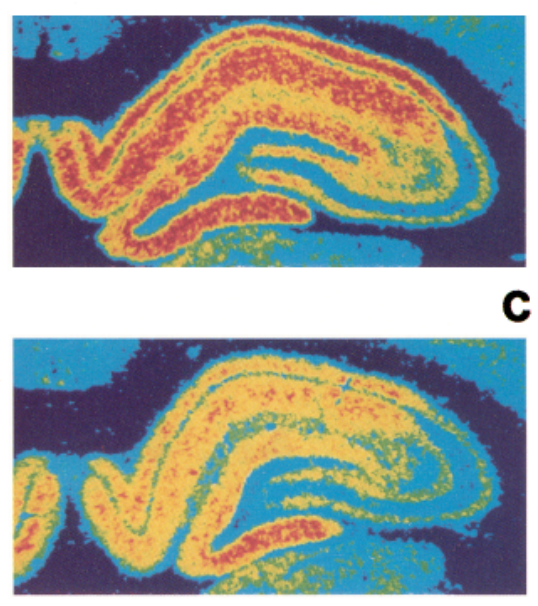

$1 w$
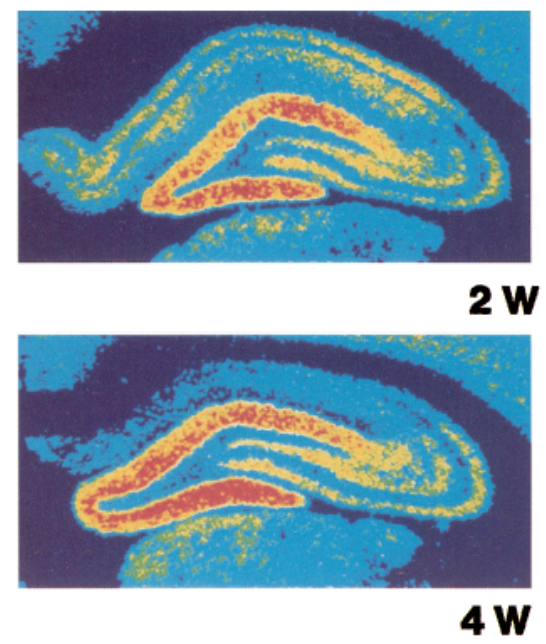

fmol/mg protein

2500

1875

1250

625

0
KA
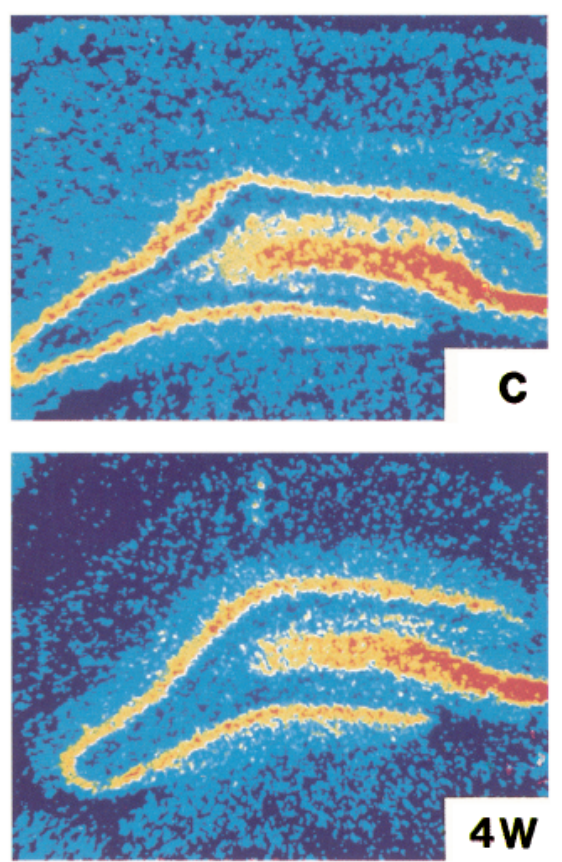

fmol/mg protein

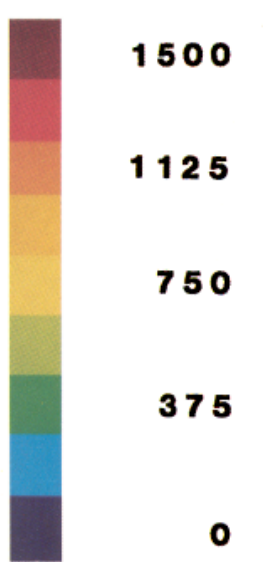



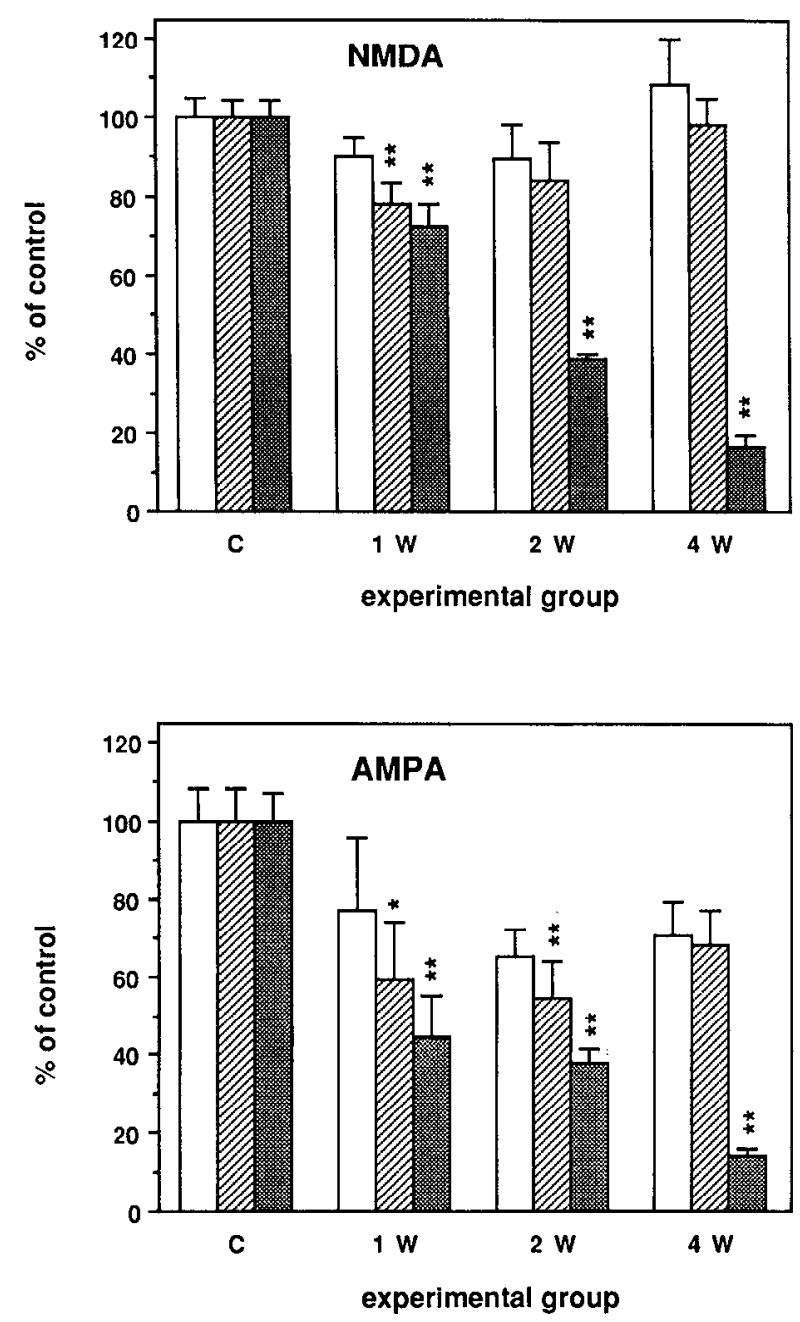

Figure 3. ${ }^{3} \mathrm{H}$-glutamate binding to NMDA-sites and ${ }^{3} \mathrm{H}-\mathrm{AMPA}-$-binding to QUIS-sites expressed as percentage of control binding (see Table $1) \pm \mathrm{SEM}, 1(n=4), 2(n=4)$, and $4(n=4)$ weeks following $10 \mathrm{~min}$ transient ischemia. The 1 week recovery group was run together with and compared with a separate control group $(n=8)$, while the other 2 experimental groups were compared with the control group $(n=14)$ in Table 1 . The structures shown are the outer two-thirds of the molecular layer of dentate gyrus ventral blade (open bars) and dorsal blade (hatched bars) and the stratum radiatum of CAl (gray bars). ${ }^{*} p<0.05,{ }^{* *} p<$ 0.01 , analysis of variance (ANOVA) with Dunnett's test.

ing in the dorsal blade of the dentate gyrus was significantly reduced $2 \mathrm{~d}$ following ischemia as well as after 1 and 2 weeks of recovery, while at 4 weeks following ischemia the binding was no longer significantly different from control values. Binding to the ventral blade was also decreased but not significantly different from control levels at any recovery period studied.

Evaluation of the binding saturation kinetics in stratum radiatum of CA1 revealed a nonlinear Scatchard plot that fitted a 2-site model with a high- and low-affinity binding site. In control animals, linear-regression analysis gave dissociation constants of $44.0 \pm 9.1$ and $213 \pm 37.0 \mathrm{~nm}$ for the high- and low-affinity binding sites, respectively (Table 2 ). The maximal number of binding sites was $1.93 \pm 0.13$ and $4.36 \pm 0.66 \mathrm{pmol} /$ $\mathrm{mg}$ protein for the high- and low-affinity site, respectively. No changes in binding affinity were found during ischemia or recirculation. However, the $B_{\max }$ value decreased during ischemia for both binding sites and was further reduced in the recircu-

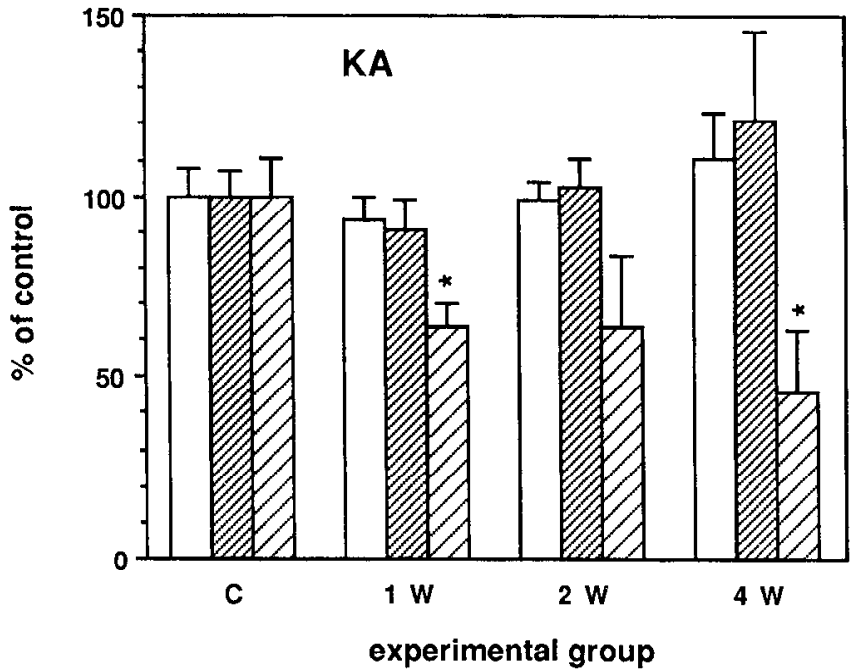

Figure 4. ${ }^{3} \mathrm{H}-\mathrm{KA}$ binding to the inner third of the dentate gyrus molecular layer ventral blade (open bars), dorsal blade (hatched bars), and hilus (striped bars) is shown as percentage of control. Control values were $883 \pm 66,758 \pm 52$, and $388 \pm 41 \mathrm{pmol} / \mathrm{mg}$ protein in the 3 structures, respectively. The groups are the same as in Figure $3 .{ }^{*} p<$ 0.05 , analysis of variance (ANOVA) with Dunnett's test.

lation period. Two days following ischemia, only $45 \%$ of the high-affinity binding sites remained. The affinity of AMPA for the QUIS receptor reported here, is considerably higher than in previous investigations (Monaghan et al., 1984). This is probably due to the inclusion of KSCN into the incubation medium, since the thiocyanide ion has been reported to increase the affinity for AMPA without altering the $B_{\max }$ (Honoré and Nielsen, 1985).

\section{Binding to $K A$ receptors}

The highest density KA binding sites within the hippocampus $(2716 \pm 57 \mathrm{fmol} / \mathrm{mg}$ protein) was found in the stratum lucidum of the CA3, with moderate binding found in the inner third of the molecular layer and in the hilus of dentate gyrus (Fig. 2). Significant changes in KA receptor binding following ischemia were seen in the hilus of dentate gyrus. In this region, the KA binding was reduced after $1-4$ weeks of recovery (Fig. 4). No significant changes in density and distribution of KA binding sites were found in the molecular layer of the dorsal or ventral blades of the dentate gyrus over the expermiental periods studied.

\section{Measurements of regional tritium quenching}

The low energy of the $\beta$-emission from tritium nuclei is subject to differences in tissue quenching between white and gray matter structures (Kuhar and Unnerstall, 1985). Since the neuronal damage postischemia is accompanied by extensive gliosis, a higher degree of quenching might be anticipated in the late recovery phase. The regional optical densities in the autoradiograms obtained from untreated and chloroform-rinsed sections were compared in the hippocampus (stratum lacunosum moleculare, CA1 stratum radiatum, dorsal and ventral blade of the dentate gyrus). The increase in optical density following chloroform treatment varied between 12.3 and $40.6 \%$ between the different regions, with the highest level of quenching found in the gray matter region cerebral cortex. No differences in quenching were found between control and experimental animals. Since 
Table 1. Binding of EAA receptors during and following $10 \mathrm{~min}$ of ischemia in $\mathrm{fmol} / \mathrm{mg}$ protein in the rat hippocampus

NMDA-displaceable ${ }^{3} \mathrm{H}$-glutamate binding

\begin{tabular}{|c|c|c|c|c|c|c|c|}
\hline Group & $n$ & CAl rad med & CAl rad lat & CA1 or & CA3 or & DG dors & DG ventr \\
\hline Control & 14 & $1742 \pm 91$ & $1848 \pm 81$ & $1774 \pm 76$ & $854 \pm 39$ & $1585 \pm 71$ & $1728 \pm 85$ \\
\hline Ischemia & 6 & $1535 \pm 99$ & $1777 \pm 114$ & $1765 \pm 120$ & $780 \pm 36$ & $1512 \pm 55$ & $1583 \pm 59$ \\
\hline Ischemia $+1 \mathrm{~d}$ & 6 & $1438 \pm 63$ & $1577 \pm 86$ & $1512 \pm 45$ & $707 \pm 55$ & $1481 \pm 79$ & $1593 \pm 71$ \\
\hline \multirow[t]{2}{*}{ Ischemia $+2 \mathrm{~d}$} & 6 & $1312 \pm 116^{a}$ & $1472 \pm 88^{\circ}$ & $1450 \pm 129^{a}$ & $635 \pm 51^{a}$ & $1212 \pm 70^{b}$ & $1385 \pm 66$ \\
\hline & & \multicolumn{6}{|c|}{${ }^{3} \mathrm{H}$-AMPA binding to quisqualate sites } \\
\hline Group & $n$ & CAl pyr med & CAl rad med & CA1 pyr lat & CA1 rad lat & DG dors & DG ventr \\
\hline Control & 14 & $1791 \pm 118$ & $1517 \pm 99$ & $1797 \pm 131$ & $1698 \pm 128$ & $1300 \pm 113$ & $1465 \pm 121$ \\
\hline Ischemia & 6 & $1440 \pm 86$ & $1161 \pm 132$ & $1447 \pm 70$ & $1285 \pm 86^{a}$ & $1005 \pm 25$ & $1109 \pm 35$ \\
\hline Ischemia $+1 \mathrm{~d}$ & 6 & $1488 \pm 109$ & $1394 \pm 126$ & $1571 \pm 110$ & $1515 \pm 115$ & $1258 \pm 95$ & $1557 \pm 125$ \\
\hline Ischemia $+2 \mathrm{~d}$ & 6 & $878 \pm 103^{b}$ & $853 \pm 108^{b}$ & $1024 \pm 168^{b}$ & $1006 \pm 131^{b}$ & $856 \pm 91^{a}$ & $1141 \pm 140$ \\
\hline
\end{tabular}

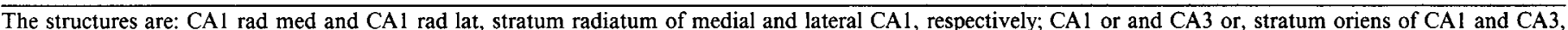

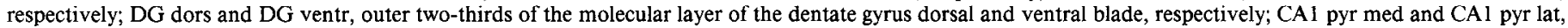
the pyramidal cell layer of medial and lateral CA1, respectively. [ ${ }^{3} \mathrm{H}$-glutamate] or [ $\left.{ }^{3} \mathrm{H}-\mathrm{AMPA}\right]$ was $100 \mathrm{nM}$. Values are given as means \pm SEM.

${ }^{a} p<0.05,{ }^{b} p<0.01$, analysis of variance with post hoc Dunnett's test.

the present results reveal no difference in quenching between controls and transient ischemia with 2 weeks of recovery, increased quenching is not a probable cause of the observed loss of radioligand binding.

\section{Discussion}

The following discussion will focus on 2 major findings of the present investigation. The first finding is a lack of correlation between receptor changes in the early recovery period following ischemia and development of neuronal necrosis in different hippocampal regions. The second finding is long-lasting receptor changes in areas considered resistant to an ischemic insult.

The postischemic changes in receptor properties in the different hippocampal regions reflect processes that are potentially reversible or processes associated with cellular destruction. Examples of reversible phenomena are receptor downregulation or decrease in receptor protein concentrations duc to dccrcased replenishment or degraded receptor due to normal turnover concomitant with decreased receptor synthesis. A decrease in receptor number could also be due to gross cellular destruction and tissue resorption.

\section{NMDA receptors}

The latter explanation most probably accounts for the decrease in NMDA receptor binding in the CAl region $2-4$ weeks fol- lowing ischemia when extensive neuronal necrosis, tissue resorption, and gliosis is seen. However, the mechanism mediating the $20-25 \%$ decrease in binding observed 2-7 d postischemia is more complex, and potentially reversible. Two findings suggest that the changes are not directly associated with gross cell degeneration. First, in the ischemia-resistant dorsal blade of the dentate gyrus, the $20 \%$ decrease in binding at 2 and $7 \mathrm{~d}$ postischemia was reversible. A decrease in binding of the same magnitude was also observed in the CAl region of 2 brains that displayed no neuronal necrosis after $2 \mathrm{~d}$ of recirculation. This could reflect a transient decrease in the receptor density due to reversible downregulation or to a transient inhibition of protein synthesis (Thilmann et al., 1986). Surprisingly, although extensive dendritic degeneration in the stratum radiatum was evident $7 \mathrm{~d}$ following ischemia, still only about $25 \%$ of the binding was lost in CA1. This could be explained by glutamate binding to postsynaptic sites on the remaining, quite large plasma membrane fragments. Another possible explanation is binding to internalized or uncovered receptors (Baudry and Lynch, 1979, 1980) or to presynaptic NMDA receptors (Collingridge et al., 1983 ) in the well-preserved axonal terminals. The relative preservation of binding to NMDA sites may also be due to an increase in the number of receptors per neuron, as recently reported in Alzheimer's disease (Bridges et al., 1988). Although we do not know the functional effect of this glutamate binding

Table 2. Kinetic constants for the binding of ${ }^{3} \mathrm{H}-\mathrm{AMPA}$ to the stratum radiatum of the CAl region

\begin{tabular}{|c|c|c|c|c|c|}
\hline \multirow[b]{2}{*}{ Group } & \multirow[b]{2}{*}{$n$} & \multicolumn{2}{|c|}{ High-affinity site } & \multicolumn{2}{|c|}{ Low-affinity site } \\
\hline & & $K_{d}(\mathrm{nM})$ & $\begin{array}{l}B_{\max } \\
(\mathrm{fmol} / \mathrm{mg} \\
\text { protein) }\end{array}$ & $K_{d}(\mathrm{nM})$ & $\begin{array}{l}B_{\max } \\
\text { (fmol/mg } \\
\text { protein) }\end{array}$ \\
\hline Control & 6 & $44.0 \pm 9.1$ & $1933 \pm 131$ & $213.0 \pm 37.0$ & $4356 \pm 659$ \\
\hline Ischemia & 6 & $46.8 \pm 14.0$ & $1416 \pm 301$ & $245.8 \pm 54.0$ & $3643 \pm 287$ \\
\hline Ischemia $+1 \mathrm{~d}$ & 6 & $43.2 \pm 8.4$ & $1516 \pm 191$ & $279.2 \pm 63.9$ & $4299 \pm 863$ \\
\hline Ischemia $+2 \mathrm{~d}$ & 5 & $46.3 \pm 15.9$ & $862 \pm 157^{a}$ & $295.0 \pm 96.0$ & $2614 \pm 387$ \\
\hline
\end{tabular}

Nine concentrations (5-500 nM) of tritiated AMPA were used and the data was fitted into Scatchard plots. Values are given as means \pm SEM.

${ }^{a} p<0.05$, analysis of variance (ANOVA) with Dunnett's test. 
to these fragments, it indicates that the receptor protein is surprisingly resistant to the severe degenerative processes. The cytotoxic properties of EAAs mediated through the NMDA receptor are well documented (Olney et al., 1981). Thus, if functionally active postischemia, the receptor could exert a deleterious influence on the neuron up to the point of total cellular disintegration.

\section{QUIS receptors}

The AMPA binding to QUIS receptors displayed changes similar to those observed for the NMDA receptor, although the magnitude of the changes was larger. In addition, some changes specific to the QUIS receptor were also found.

The observed early postischemic ( $2 \mathrm{~d}$ ) decrease in the binding of AMPA to the CA1 region, corroborates our previously reported results (Westerberg et al., 1987). In the present investigation, there was also a significant decrease in binding at the end of the $10 \mathrm{~min}$ ischemia period. Binding kinetics revealed that the decrease was due to loss of high-affinity binding sites and not due to alterations in the dissociation constant. One possible explanation to the biphasic change in AMPA binding could be a downregulation of the AMPA receptors due to transient increase in the extracellular levels of excitatory transmitters during ischemia and the immediate postischemic phase (Benveniste et al., 1984), and with a possible second release of transmitters 2-3 d postischemia.

Similar to what was found for NMDA receptors, the AMPA binding sites were lost in areas of cell necrosis 1-4 weeks following ischemia. However, some major differences between the 2 receptor classes can be discerned. Seven days postischemia, the AMPA binding decreased by $60 \%$. This decrease was substantially larger than the corresponding loss of NMDA receptor binding, indicating that the receptor is more sensitive to alterations of its microenvironment.

The changes in AMPA binding in the ischemia-resistant dentate gyrus were extensive. Binding in both the dorsal and ventral blade was decreased $2 \mathrm{~d}$ postischemia, but the change was significant only in the dorsal blade. The decrease in AMPA binding in the dorsal blade persists at least up to 2 weeks following the ischemic insult. This demonstrates a persistent postischemic modulation of EAA receptors not associated with cell death. The decrease in binding is probably not due to a depressed protein synthesis since this is normalized in the dentate gyrus by $1 \mathrm{~d}$ postischemia (Thilmann et al., 1986). The change in the binding could be an adaptation to the new functional state of the damaged hippocampus. The decrease in AMPA binding could possibly explain the postischemic decrease in glucose metabolism in this region (Pulsinelli et al., 1982b), since in contrast to the NMDA receptor, the QUIS/KA receptors have been demonstrated to be the major component of the synaptic response in the hippocampal excitatory pathways (Koerner and Cotman, 1982; Ganong et al., 1986).

\section{$K A$ binding}

The polymorphic cells in the hilus of the dentate gyrus are among the most ischemia-sensitive neurons in the rat brain (Smith et al., 1984a). Within $24 \mathrm{hr}$ following ischemia, extensive necrosis of these vulnerable somatostatin-containing neurons can be seen (Kirino, 1982; Pulsinelli et al., 1982a; Johansen et al., 1987). The inner third of the molecular layer of the dentate granule cells displaying a high density of binding sites receives a dense, presumably glutamatergic innervation from the contralateral and ipsilateral hilus. Changes in the KA receptors could thus be anticipated following extensive loss of hilar cells. The present investigation did not show any changes in density or distribution of KA binding sites in the molecular layer. However, KA binding in the hilus decreased significantly by $40 \%$ a week following ischemia. No significant loss of binding was found after shorter periods of recovery, despite the fact that these hilar cells succumb within hours following the ischemic insult.

\section{Conclusions}

In the present investigation we have demonstrated the presence of 2 apparently concurrent processes leading to changes in receptor density, one process potentially reversible and another possibly associated with cell loss. The different receptors display differences in response to these processes. In particular, the NMDA receptor seems to be strikingly resistant to degenerative processes. Furthermore, neurons that survive an ischemic insult are subject to long-lasting decrease in QUIS receptor density. This suggests that, apart from a detrimental effect of ischemia on the integrity of cellular structures that ultimately leads to neuronal death, ischemia may also induce long-term changes in the properties of the surviving neurons. Functionally, this could be expressed as changes in neuronal transmission and animal or human behavior. This warrents caution in interpreting behavioral changes in animals subjected to a transient ischemic insult as merely a consequence of neuronal loss. The clinical implications of our study are that apart from striving to find therapeutic ways to ameliorate ischemic neuronal necrosis, efforts should also be directed to protect the brain against ischemia-induced cellular changes not associated with or leading to neuronal death.

\section{References}

Baudry, M., and G. Lynch (1979) Regulation of glutamate receptors by cations. Nature $282: 748-750$.

Baudry, M., and G. Lynch (1980) Regulation of hippocampal glutamate receptors: Evidence for the involvement of a calcium-activated protease. Proc. Natl. Acad. Sci. USA 77: 2298-2302.

Benveniste, H., J. Drejer, A. Schousboe, and N. H. Diemer (1984) Elevation of the extracellular concentrations of glutamate and aspartate in rat hippocampus during transient cerebral ischemia monitored by intracerebral microdialysis. J. Neurochem. 43: 1369-1374.

Bridges, R. J., J. W. Geddes, D. T. Monaghan, and C. W. Cotman (1988) Excitatory amino acids in Alzheimers disease. In Excitatory Amino Acids in Health and Disease, D. Lodge, ed., pp. 321-334, Wiley, London.

Collingridge, G. L., S. J. Kehl, and H. McLennan (1983) Excitatory amino acids in synaptic transmission in the Schaffer collateral-commissural pathway of the rat hippocampus. J. Physiol. (Lond.) 334: $33-46$.

Ganong, A. H., A. W. Jones, J. C. Watkins, and C. W. Cotman (1986) Parallel antagonism of synaptic transmission and kainate/quisqualate responses in the hippocampus by piprazine-2,3-dicarboxylic acid analogs. J. Neurosci. 6: 930-937.

Geary II, W. A., A. W. Toga, and G. F. Wooten (1985) Quantitative film autoradiography for tritium: Methodological considerations. Brain Res. 337: 99-108.

Gill, R., A. C. Fostcr, and G. N. Woodruff (1987) Systemic administration of MK-801 protects against ischaemia-induced hippocampal neurodegeneration in the gerbil. J. Neurosci. 7: 3343-3349.

Honoré, T., and M. Nielsen (1985) Complex structure of quisqualate sensitive glutamate receptors in cat cortex. Neurosci. Lett. 54: 2732.

Ito, U., M. Spatz, J. T. Walker, and I. Klatzo (1975) Experimental cerebral ischemia in mongolian gerbils. Acta Neuropathol. (Berl.) 32: 209-223.

Johansen, F. F., M. B. Jørgensen, and H. H. Diemer (1987) Colchicine degranulation of the dentate gyrus protects the hippocampus CA1 
region from ischemic damage. In Excitatory Amino Acid Transmission, T. P. Hicks, D. Lodge, and H. McLennan, eds., pp. 241-244, Liss, New York.

Jørgensen, M. B., and N. H. Diemer (1982) Selective neuron loss after cerebral ischemia in the rat: Possible role of transmitter glutamate. Acta Neurol. Scand. 66: 536-546.

Jørgensen, M. B., F. F. Johansen, and N. H. Dicmer (1987) Removal of the entorhinal cortex protects hippocampal CA1 neurons from ischemic damage. Acta Neuropathol. (Berl.) 73: 189-194.

Kirino, T. (1982) Delayed neuronal death in the gerbil hippocampus following ischemia. Brain Res. 239: 57-69.

Koerner, J. F., and C. W. Cotman (1982) Response of Schaffer collateral-CA1 pyramidal cell synapses of the hippocampus to analogues of acidic amino acids. Brain Res. 251: 105-115.

Kuhar, M. J., and J. R. Unnerstall (1985) Quantitative receptor mapping by autoradiography: Some current technical problems. TINS 8 : 49-53.

Monaghan, D. T., V. R. Holets, D. W. Toy, and C. W. Cotman (1983) Anatomical distributions of four pharmacologically distinct ${ }^{3} \mathrm{H}$-glutamate binding sites. Nature (London) 306: 176-179.

Monaghan, D. T., D. Yao, and C. W. Cotman (1984) Distribution of $\left[{ }^{3} \mathrm{H}\right] A M P A$ binding sites in rat brain as determined by quantitative autoradiography. Brain Res. 324: 160-164.

Olney, J. W., J. Labruyere, J. F. Collins, and K. Curry (1981) D-Aminophosphovarerate is 100 -fold more powerful than D-alphaaminoadipate in blocking $\mathrm{N}$-methylaspartate neurotoxicity. Brain Res. 221: 207-210.

Pulsinelli, W. A., J. B. Brierly, and F. Plum (1982a) Temporal profile of neuronal damage in a model of transient forebrain ischemia. Ann. Neurol. 11: 491-498.

Pulsinelli, W. A., D. E. Levy, and T. E. Duffy (1982b) Regional cerebral blood flow and glucose metabolism following transient forebrain ischemia. Ann. Neurol. 11: 499-509.

Rothman, S. M. (1983) Synaptic activity mediates death of hypoxic neurons. Science 220: 536-537.
Simon, R. P., J. H. Swan, T. Griffith, and B. S. Meldrum (1984) Blockade of $N$-methyl-D-aspartate receptors may protect against ischemic damage in the brain. Science 226:850-852.

Smith, M.-I., R. N. Auer, and B. K. Siesjö (1984a) The density and distribution of ischemic brain injury in the rat following 2-10 min of forebrain ischemia. Acta Neuropathol. (Berl.) 64: 319-332.

Smith, M.-L., G. Bendek, N. Dahlgren, I. Rosén, T. Wieloch, and B. K. Siesjö (1984b) Models for studying long-term recovery following forebrain ischemia in the rat. A 2-vessel occlusion model. Acta Neurol. Scand. 69: 385-401.

Smith, M.-L., H. Kalimo, D. S. Warner, and B. K. Siesjö (1988) Morphological lesions in the brain preceding the development of postischemic seizures. Acta Neuropathol. (Berl.) 76: 253-264.

Sokoloff, L., M. Reivich, C. Kennedy, M. H. Des Rosiers, C. S. Patlak, K. D. Pettigrew, O. Sakurada, and M. Shinohara (1977) The ${ }^{14} \mathrm{C}-$ deoxyglucose method for the measurement of local cerebral glucose utilization: Theory, procedure, and normal values in the conscious and anaesthetized albino rat. J. Neurochem. 28: 897-916.

Thilmann, R., Y. Xie, P. Kleihues, and M. Kiessling (1986) Persistent inhibition of protein synthesis precedes delayed neuronal death in postischemic gerbil hippocampus. Acta Neuropathol. (Berl.) 71: 8893.

Unnerstall, J. R., D. L. Niehoff, M. J. Kuhar, and J. M. Palacios (1982) Quantitative autoradiography using $\left[{ }^{3} \mathrm{H}\right]$ Ultrofilm: Application to multiple benzodiazepine receptors. J. Neurosci. Methods 6: 59-73.

Watkins, J. C., and R. H. Evans (1981) Excitatory amino acid transmitters. Annu. Kev. Pharmacol. Toxicol. 21: 165-204.

Westerberg, E., D. T. Monaghan, C. W. Cotman, and T. Wieloch (1987) Excitatory amino acid receptors and ischemic brain damage in the rat. Neurosci. Lett. 73: 119-124.

Wieloch, T. (1985) Neurochemical correlates to selective neuronal vulnerability. Prog. Brain Res. 63: 69-85.

Wieloch, T., O. Lindvall, P. Blomqvist, and F. Gage (1985) Evidence for amelioration of ischemic neuronal damage in the hippocampal formation by lesions of the perforant path. Neurol. Res. 7: 24-26. 